Vol 3 No 2 (2020) 198-209 P-ISSN 2620-295 E-ISSN 2747-0490 DOI: 1047467/elmal.v3i2.569

\title{
Persepsi Mahasiswa Perbankan Syariah Semester II Tentang Penggunaan Aplikasi Google Classroom Selama Perkuliahan Daring Pada Masa Pandemi Covid-19
}

\author{
Khairunnisa ${ }^{1}$, Sri Wahyuni Hasibuan ${ }^{2}$, Syafriah Anjani ${ }^{3}$, Azhari ${ }^{4}$ \\ STAI Jam'iyah Mahmudiyah Tanjung Pura Kabupaten Langkat \\ e-mail: ayong.nisarao1@gmail.com
}

\begin{abstract}
This study aims to describe the perceptions of second semester Islamic banking students regarding the use of the Google Classroom application during online lectures during the COVID-19 pandemic. Online lectures are one of the terms used during the COVID-19 pandemic which means lectures that are carried out on a network and connected via the internet. The perceptions of students studied were limited to aspects of teaching and learning, lecturers' capabilities or abilities, and facilities and infrastructure during the implementation of online lectures through the Google Classroom application. This research is a descriptive research with a qualitative approach. The subjects of this study were all second semester Islamic banking students who had attended online lectures in the economic mathematics course at the Jam'iyah Mahmudiyah Islamic High School Tanjung Pura, Langkat Regency, for the 2019/2020 academic year. Data were collected using a questionnaire filled out online by students. The data analysis technique used in this research is qualitative analysis which consists of data collection, data reduction, data presentation, and drawing conclusions. The results showed that the second semester Islamic banking students' perceptions of using the Google Classroom application during online lectures during the COVID-19 pandemic were in the good category. However, students still prefer lectures to be held face-to-face.
\end{abstract}

Keywords: student perception; google classsroom application; online classes

\begin{abstract}
ABSTRAK
Penelitian ini bertujuan untuk mendeskripsikan persepsi mahasiswa perbankan syari'ah semester II tentang penggunaan aplikasi Google Classroom selama perkuliahan daring pada masa pandemi covid-19. Perkuliahan daring merupakan salah satu istilah yang digunakan selama masa pandemi covid-19 yang berarti perkuliahan yang dilaksanakan dalam jaringan dan terhubung melalui internet. Persepsi mahasiswa yang diteliti terbatas hanya pada aspek belajar mengajar, kapabilitas atau kemampuan dosen, dan sarana dan prasarana selama pelaksanaan perkuliahan daring melalui aplikasi google classroom. Penelitian ini merupakan penelitian deskriptif dengan pendekatan kualitatif. Subjek penelitian ini adalah seluruh mahasiswa perbankan syari'ah semester II yang telah mengikuti perkuliahan daring pada mata kuliah matematika ekonomi Sekolah Tinggi Agama Islam Jam'iyah Mahmudiyah Tanjung Pura Kabupaten Langkat tahun akademik 2019/2020. Data dikumpulkan dengan menggunakan kuesioner yang diisi secara online oleh mahasiswa. Teknik analisis data yang digunakan pada penelitian ini adalah analisis kualitatif yang terdiri atas pengumpulan data, reduksi data, penyajian data, dan penarikan kesimpulan. Hasil penelitian menunjukkan bahwa persepsi mahasiswa perbankan syari'ah semester II tentang penggunaan aplikasi google classroom selama perkuliahan daring pada masa pandemi covid-19 berada pada kategori baik. Namun, mahasiswa tetap lebih menginginkan perkuliahan dilaksanakan secara tatap muka.
\end{abstract}

Kata kunci: persepsi mahasiswa; aplikasi google classroom; perkuliahan secara daring 
Vol 3 No 2 (2020) 198-209 P-ISSN 2620-295 E-ISSN 2747-0490 DOI: 1047467/elmal.v3i2.569

\section{PENDAHULUAN}

Bermula dari penyebaran Coronavirus Disease atau virus corona yang terjadi pada akhir tahun 2019 di Wuhan, China. Virus corona atau lebih dikenal dengan istilah pandemi covid-19 memberikan dampak yang sangat signifikan terhadap keadaan di dunia, baik ekonomi, sosial, kesehatan, bahkan pendidikan. Di Indonesia, pandemi covid-19 ini mewabah pada awal tahun 2020, sehingga membuat pemerintah pusat hingga daerah mengeluarkan kebijakan untuk meliburkan seluruh lembaga pendidikan. Hal ini dilakukan demi meminimalisir penyebaran virus covid19 lebih luas. Badan Nasional Penanggulangan Bencana (BNPB) mengeluarkan surat keputusan nomor 13A tertanggal 17 Maret 2020 terkait penetapan status keadaan darurat bencana wabah penyakit akibat virus corona di Indonesia (BNBP RI, 2020). Berdasarkan keputusan tersebut, Menteri Pendidikan dan Kebudayaan juga mengeluarkan surat edaran pada 17 Maret 2020 agar pembelajaran dilaksanakan secara daring dan bekerja dari rumah untuk mencegah penyebaran COVID-19 (Kemendikbud, 2020). Hal ini juga berlaku bagi perguruan tinggi untuk melaksanakan perkuliahan dari rumah sebagaimana surat edaran Dirjen Dikti Kementerian Pendidikan dan Kebudayaan Nomor 1 Tahun 2020 tentang pencegahan penyebaran virus corona di Perguruan Tinggi. Dalam surat edaran tersebut berisi tentang himbauan agar perguruan tinggi melaksanakan pembelajaran jarak jauh sesuai dengan kondisi masing-masing, dan menyarankan mahasiswa untuk melakukan pembelajaran dari rumah.

Berdasarkan kebijakan tersebut, maka perguruan tinggi juga melaksanakan perkuliahan dari rumah. Perkuliahan tersebut dikenal dengan istilah perkuliahan secara daring atau perkuliahan online. Dalam pelaksanaannya, perkuliahan secara daring memerlukan sarana dan prasarana yang memadai agar tercipta perkuliahan yang baik antara dosen dan mahasiswa. Perkuliahan secara daring membutuhkan alat komunikasi yang dapat menghubungkan antara dosen dan mahasiswa di dalam kegiatan belajar mengajar secara online. Maka, setiap dosen dan mahasiswa dituntut untuk dapat menggunakan berbagai aplikasi yang dapat menghubungkan keduanya dalam perkuliahan daring, salah satunya dengan menggunakan aplikasi google classroom atau sering disingkat dengan istilah GC.

Aplikasi google classroom telah ada dan digunakan sebelum mewabahnya covid-19. Namun, semenjak covid-19 dan diberlakukankannya pembelajaran dari rumah, aplikasi ini menjadi salah satu aplikasi pilihan yang digunakan oleh pendidik dalam pembelajaran secara daring. Google classroom merupakan sebuah aplikasi yang dapat menciptakan ruang kelas secara online sehingga dapat menjadi media 


\section{Cl, MITIV Iurnal Kajian Ekonomi \& Bisnis Islam}

\section{Vol 3 No 2 (2020) 198-209 P-ISSN 2620-295 E-ISSN 2747-0490 DOI: 1047467/elmal.v3i2.569}

penyampaian materi, pendistribusian dan pengumpulan tugas oleh mahasiswa. Bahkan google classroom menyediakan fitur penilaian langsung terhadap tugas-tugas yang telah dikumpulkan oleh mahasiswa. Sehingga menjadi salah satu daya tarik bagi mahasiswa untuk mengerjakan dan mengumpulkan tugas-tugas yang diberikan oleh dosen. Selain itu, google classroom menyediakan fitur untuk mengunggah video atau menautkan link video dari YouTube dan terdapat forum diskusi sehingga dosen bisa membuka sebuah diskusi kelas seperti di Facebook yang dapat ditanggapi dan dikomentari.

Studi literatur mengenai penggunaan google classroom dalam perkuliahan secara daring bagi mahasiswa perguruan tinggi menghasilkan bahwa google classroom menjadi teknologi komunikasi yang banyak digunakan dalam proses pembelajaran e-learning (Hapsari dan Pamungkas, 2019:231). Kelayakan penyajian kelas online menggunakan google classroom diperoleh prosentase sebesar 81,79\%, hal ini menyatakan bahwa desain yang dirancang sudah memenuhi teknik penyajian meliputi kesesuaian antar konsep, kekonsistenan sistematika dan keseimbangan antar Bab pada materi (Septantiningtyas, 2019:106). Berdasarkan hasil penelitian yang telah dipaparkan, perkuliahan secara daring melalui aplikasi google classroom menjadi salah satu alternatif komunikasi dalam melaksanakan pembelajaran tanpa mengurangi inti dari materi perkuliahan yang diberikan oleh dosen, dan menjembatani atau memfasilitasi komunikasi antara dosen dan mahasiswa. Bahkan komitmen terhadap pelaksanaan perkuliahan sama halnya dengan perkuliahan secara luring (luar jaringan). Fokus penelitian ini yaitu mahasiswa aktif program studi perbankan syariah semester genap tahun akademik 2019/2020 yang mengikuti perkuliahan secara daring pada mata kuliah matematika ekonomi di Sekolah Tinggi Agama Islam Jam'iyah Mahmudiyah Tanjung Pura Kabupaten Langkat. Sedangkan rumusan masalah dalam penelitian ini adalah "Bagaimanakah persepsi mahasiswa perbankan syari' ah semester II tentang penggunaan aplikasi google classroom selama perkuliahan daring pada masa pandemi covid-19 tahun akademik 2019/2020?; dan apakah yang menjadi pendukung dan penghambat pada penggunaan aplikasi google classroom selama perkuliahan daring pada masa pandemi covid-19?".

\section{TINJAUAN LITERATUR}

Sejak diberlakukannya pembelajaran dari rumah pada masa pandemi covid19, maka semakin banyak pula aplikasi yang digunakan dalam pembelajaran dari rumah atau pembelajaran secara daring dengan menggunakan alat bantu berupa handphone dan atau komputer/laptop. Namun, pembelajaran secara daring ini tentunya memperlukan kuota internet bahkan jaringan internet yang stabil agar pembelajaran secara daring dapat berjalan secara baik sesuai dengan yang diharapkan oleh pendidik dan peserta didik. Walaupun dalam kenyataannya, sinyal atau jaringan internet masih menjadi kendala dalam pembelajaran secara daring yang disebabkan oleh lokasi tempat tinggal ataupun kartu internet pendukung yang digunakan oleh pendidik atau peserta didik dalam pembelajaran secara daring. Apalagi diperlukan persiapan yang matang sebelum melaksanakan pembelajaran 
Vol 3 No 2 (2020) 198-209 P-ISSN 2620-295 E-ISSN 2747-0490 DOI: $1047467 /$ elmal.v3i2.569

secara daring agar dapat memaksimalkan penyampaian materi pelajaran yang akan diberikan kepada peserta didik.

\section{Media Internet}

Internet merupakan salah satu media pembelajaran yang berkembang pesat hingga saat ini. Hal ini mengakibatkan setiap orang menggunakan internet dalam kegiatan sehari-harinya, terutama dalam dunia pendidikan saat ini seiring dengan mewabahnya pandemi covid-19, sehingga menuntut guru/dosen dan murid/mahasiswa untuk dapat menggunakan internet. Oleh karena itu, pengguna internet sudah tidak lagi mengenal usia, sebagaimana yang diungkapkan oleh Arsyad (2013: 194) bahwa perkembangan dunia internet kini menjadi sangat pesat, tidak mengenal usia, bahkan jabatan seseorang, seakan setiap orang dipaksa untuk mengenal bahkan menggunakan dunia maya ini. Arsyad (2013: 195) juga memberikan pengertian tentang internet sebagai sebuah jaringan komputer yang saling terhubung dan dapat berkomunikasi satu sama lain secara global/internasional baik melalui kabel, radio, satelit, dan lain-lain. Sedangkan Smaldino, dkk (2011: 247) menyatakan bahwa internet merupakan sistem seluruhdunia untuk menghubungkan jaringan-jaringan komputer yang lebih kecil bersamasama. Siapa pun yang terhubung di internet bisa berkomunikasi dengan siapa pun, bahkan para pengguna bisa mengakses informasi apa pun, terlepas dari jenis komputer yang mereka miliki, karena adanya protokol standar yang memungkinkan seluruh komputer untuk saling berkomunikasi satu sama lain. Sehingga, dapat disimpulkan bahwa dunia internet dapat memberikan informasi apa pun bagi para penggunanya, bahkan menjalin komunikasi antara yang satu dengan lainnya secara nyata tanpa mengenal jarak, baik melalui jaringan komputer atau melalui telepon genggam atau gadget kita.

Konsep tentang dunia internet tentunya menimbulkan hal-hal positif dan negatif. Hal-hal positif merupakan sebuah kelebihan atau keunggulan dari internet, sedangkan hal-hal negatif menjadi suatu kekurangan atau keterbatasan bahkan memberikan pengaruh yang tidak baik bagi para pengguna internet. Salah satu kelebihan penggunaan internet saat ini adalah memberikan kemudahan bagi penggunanya dalam melakukan kegiatan sehari-hari, terutama dalam dunia pendidikan. Internet menjadi salah satu media pembelajaran yang sangat mudah untuk diterapkan oleh pengajar/pendidik. Hal itu dapat dilihat dari adanya penerapan konsep e-learning atau konsep pembelajaran jarak jauh, yaitu kegaiatan pembelajaran yang dilakukan antara guru/dosen dan murid/mahasiswa di luar sekolah/kampus. Namun, tetap membutuhkan keahlian khusus dalam mengoperasikannya atau menerapkannya dalam pembelajaran secara daring agar tersampaikannya materi pelajaran secara maksimal sehingga tercapai tujuan pembelajaran yang dilakukan. Hal ini yang diharapkan dalam penggunaan aplikasi yang mendukung pembelajaran secara daring, salah satunya penggunaan aplikasi google classroom.

\section{Aplikasi Google Classroom}




\section{Vol 3 No 2 (2020) 198-209 P-ISSN 2620-295 E-ISSN 2747-0490 DOI: 1047467/elmal.v3i2.569}

Google Classroom atau dalam bahasa Indonesia diartikan ruang kelas google, dikenal sebagai salah satu aplikasi yang menyediakan fitur ruang kelas dalam melaksanakan pembelajaran secara daring. Google Classroom sebagai perangkat lunak telah diperkenalkan sebagai bagian dari Google Apps for Education (GAFE) sejak 12 Agustus 2014. Google Classroom atau lebih dikenal dengan singkatan GC juga menjadi salah satu aplikasi yang umumnya digunakan oleh para guru/dosen dalam menyampaikan materi pelajaran/perkuliahan kepada murid/mahasiswa.

Menurut Asnawi (2018: 18), Google Classroom merupakan sebuah aplikasi yang diciptakan oleh Google yang memungkinkan terciptanya ruang kelas di dunia maya. Selain itu, aplikasi ini menjadi sarana dikumpulkannya tugas-tugas. Sedangkan Sukmawati dan Nensia (2019: 144) menyatakan bahwa Google Classroom is a google product that is connected with gmail, drive, hangout, youtube and a deep calendar. The many facilities provided by google classroom will make it easier for teachers to carry out learning activities. The intended learning is not only in class, but also outside the classroom because students can do learning wherever and whenever by accessing google classroom online. Hal ini dapat diartikan bahwa GC adalah produk google yang terhubung langsung dengan gmail, drive, hangout, youtube, dan kalander yang mendalam. Ada banyak fasilitas yang disediakan dalam aplikasi Google Classroom ini, yang tentunya akan memberikan kemudahan untuk guru dalam melaksanakan kegiatan pembelajaran. Pembelajaran yang dimaksud adalah pembelajaran yang tidak hanya dapat dilakukan di dalam kelas tetapi juga di luar kelas, karena siswa dapat melaksanakan pembelajaran di mana saja dan kapan pun dengan mengakses Google Classroom secara online. Hal ini juga senada dengan pernyataan Latif dalam Fauziah (2019: 184) yang memberikan pengertian tentang Google Classroom sebagai salah satu platform dari google yang membantu guru untuk membuat dan mengatur tugas kelas dengan cepat dan mudah, memberikan umpan balik kepada siswa langsung secara efisien, dan berkomunikasi bersama siswa tanpa terbatas oleh ruang dan waktu. Kemudian, pendapat ini dipertegas kembali oleh Rozak dan Albantani (2018: 86) bahwa aplikasi ini sangat memudahkan proses pembelajaran oleh dosen dan mahasiswa dalam melaksanakan proses belajar. Google Classroom sesungguhnya dirancang untuk mempermudah interaksi dosen dan mahasiswa dalam dunia maya. Aplikasi ini memberikan kesempatan kepada para dosen untuk mengeksplorasi gagasan keilmuan yang dimilikinya kepada mahasiswa. Dosen memiliki keleluasaan waktu untuk membagikan kajian keilmuan dan memberikan tugas mandiri kepada siswa. Selain itu, dosen juga dapat membuka ruang diskusi bagi para mahasiswa secara online. Namun demikian, ada syarat mutlak dalam mengaplikasikan Google Classroom, yaitu membutuhkan akses internet yang mumpuni.

Ada berbagai kelebihan/keuntungan yang dimiliki oleh apalikasi Google Classroom ini sebagaimana pernyataan yang telah diungkapkan di atas. Kelebihan/keuntungan lain yang diperoleh dari aplikasi Google Classroom ini adalah aplikasi tidak berbayar, sehingga siapa saja dapat mengunggah aplikasi ini dalam gadget atau laptop yang dimiliki. Sehingga aplikasi Google Classroom dianggap 


\section{Cl, MITIV Iurnal Kajian Ekonomi \& Bisnis Islam}

\section{Vol 3 No 2 (2020) 198-209 P-ISSN 2620-295 E-ISSN 2747-0490 DOI: 1047467/elmal.v3i2.569}

sebagai salah satu aplikasi resmi dari google yang dapat memudahkan pembelajaran/perkuliahan secara daring yang dilakukan pada masa pandemi covid19 ini, karena dapat dengan mudah di akses oleh siapa saja asal memiliki gadget atau laptop yang terhubung dengan jaringan internet yang baik.

\section{METODE PENELITIAN}

Penelitian ini merupakan jenis penelitian kualitatif. Richie dalam Moleong (2012:6) menyebutkan penelitian kualitatif adalah upaya untuk menyajikan dunia sosial dan perspektifnya dari segi konsep, perilaku, persepsi dan persoalan tentang manusia yang diteliti. Sugiyono (2014:1) menambahkan penelitian kualitatif merupakan metode penelitian yang digunakan untuk meneliti kondisi obyek yang alamiah. Pada penelitian kualitatif penulis adalah instrumen kunci (key informant). Lebih lanjut, menurut Bogdan dan Taylor dalam Sujarweni (2014: 6) menjelaskan bahwa pengertian penelitian kualitatif berkaitan dengan prosedur penelitian yang menghasilkan data secara deskriptif yang berupa ucapan atau tulisan dan perilaku orang-orang yang diamati. Pendekatan kualitatif ini diharapkan mampu menghasilkan uraian atau penjelasan secara lebih mendalam tentang ucapan, tulisan, dan atau perilaku yang dapat diamati dari suatu individu, kelompok, masyarakat, dan atau organisasi tertentu dalam suatu keadaan konteks tertentu yang dikaji dari sudut pandang yang utuh, komprehensif, dan holistik.

Penelitian ini mendeskripsikan persepsi mahasiswa perbankan syari'ah semester II tentang penggunaan aplikasi google classroom selama perkuliahan daring pada masa pandemi covid-19 tahun akademik 2019/2020?; serta faktor pendukung dan penghambat pada penggunaan aplikasi google classroom selama perkuliahan daring pada masa pandemi covid-19. Responden penelitian yaitu mahasiswa aktif perbankan syari'ah semester II tahun akademik 2019/2020 yang mengikuti perkuliahan daring mata kuliah ekonomi dan mengisi kuesioner melalui google form yaitu berjumlah 54 mahasiswa yang terdiri dari 16 laki-laki dan 38 perempuan. Teknik pengumpulan data menggunakan teknik kuesioner dan wawancara terstruktur melalui google form yang terintegrasi pada google classroom. Studi dokumentasi berupa hasil tugas setiap tatap muka perkuliahan menjadi pelengkap dalam penelitian ini. Setiap butir pertanyaan menggunakan skala ordinal, yaitu: Sangat Tidak Setuju/STS (1), Tidak Setuju/TS (2), Ragu-ragu/RR (3), Setuju/S (4), dan Sangat Setuju/ST (5). Hasil kuesioner dikelompokkan ke dalam interval seperti pada Tabel 1 berikut.

Tabel 1. Kategori Persepsi Mahasiswa

\begin{tabular}{cc}
\hline Interval & Kategori \\
\hline $1,00-1,80$ & Sangat Buruk \\
$1,81-2,60$ & Buruk \\
$2,61-3,40$ & Sedang \\
$3,41-4,20$ & Baik \\
$4,21-5,00$ & Sangat Baik \\
\hline
\end{tabular}




\section{Cl, Pl|VIV | Jurnal Kajian Ekonomi \& Bisnis Islam}

\section{Vol 3 No 2 (2020) 198-209 P-ISSN 2620-295 E-ISSN 2747-0490 DOI: 1047467/elmal.v3i2.569}

(Sumber: Sugiyono, 2012)

Penelitian dilaksanakan bulan Maret sampai Juni 2020. Teknik keabsahan data menggunakan teknik triangulasi sumber dan teknik. Triangulasi sumber digunakan menguji kredibilitas data dengan mengecek data yang diperoleh dari beberapa sumber, (Sugiono, 2012:373). Triangulasi teknik menggunakan data yang diperoleh dari angket kuesioner, wawancara dan studi dokumen berupa hasil tugas mahasiswa. Analisis data menggunakan model interaktif Miles and Huberman. Analisis interaktif terdiri dari Pengumpulan Data (Data Collection), Reduksi Data (Data Reduction), Penyajian Data (Display Data), dan Verifikasi (Conclusion Drawing).

\section{HASIL DAN PEMBAHASAN}

Kuesioner diberikan dan diisi secara online melalui google form yang juga terhubung dengan aplikasi google classroom. Kuesioner tersebut terdiri atas 17 pernyataan berdasarkan 3 aspek yaitu aspek belajar mengajar, aspek kapabilitas (kompetensi dosen), dan aspek sarana dan prasarana. Hasil kuesioner 54 responden terkait persepsi mahasiswa mengenai penggunaan aplikasi google classroom selama perkuliahan daring pada mata kuliah matematika ekonomi pada masa pandemi covid19 tertuang dalam ketiga aspek tersebut dengan rincian sebagaimana table 2 berikut:

Tabel 2. Hasil Kuesioner Responden

\begin{tabular}{|c|c|c|c|}
\hline No & Item Pernyataan & \multirow{2}{*}{ Rata-rata } & \multirow{2}{*}{ Kategori } \\
\hline \multicolumn{2}{|r|}{ A. Aspek Belajar Mengajar } & & \\
\hline 1. & $\begin{array}{l}\text { Pelaksanaan perkuliahan secara daring dapat } \\
\text { diakses } \\
\text { secara mudah }\end{array}$ & 3,39 & Sedang \\
\hline 2. & $\begin{array}{l}\text { Pelaksanaan perkuliahan secara daring tepat waktu } \\
\text { dan sesuai dengan jadwal yang telah ditetukan dan } \\
\text { disepakati }\end{array}$ & 3,68 & Baik \\
\hline 3. & $\begin{array}{l}\text { Perkuliahan secara daring menambah pemahaman } \\
\text { teori dan keterampilan }\end{array}$ & 3,38 & Sedang \\
\hline 4. & $\begin{array}{l}\text { Materi yang disajikan secara daring sesuai dengan } \\
\text { kontrak perkuliahan/RPS }\end{array}$ & 3,75 & Baik \\
\hline 5. & $\begin{array}{l}\text { Kemudahan dalam mengirimkan tugas individu } \\
\text { maupun kelompok }\end{array}$ & 3,89 & Baik \\
\hline \multicolumn{2}{|r|}{ Rata-rata Aspek A } & 3,62 & BAIK \\
\hline \multicolumn{2}{|r|}{ B. Aspek Kapabilitas (Kemampuan Dosen) } & & \\
\hline 6. & $\begin{array}{l}\text { Dosen selalu menemani ketika pembelajaran secara } \\
\text { daring hingga selesai }\end{array}$ & 4,25 & Sangat Baik \\
\hline 7. & $\begin{array}{l}\text { Dosen menjelaskan arah dan tujuan dalam setiap } \\
\text { pembelajaran secara daring }\end{array}$ & 4,01 & Baik \\
\hline
\end{tabular}


Vol 3 No 2 (2020) 198-209 P-ISSN 2620-295 E-ISSN 2747-0490 DOI: 1047467/elmal.v3i2.569

\begin{tabular}{|c|c|c|c|}
\hline 8. & $\begin{array}{l}\text { Dosen memberikan kesempatan kepada mahasiswa } \\
\text { untuk bertanya dan berdiskusi }\end{array}$ & 4,12 & Baik \\
\hline 9. & $\begin{array}{l}\text { Dosen memberikan respon terhadap pertanyaan } \\
\text { yang muncul selama perkuliahan secara daring }\end{array}$ & 4,19 & Baik \\
\hline 10. & $\begin{array}{l}\text { Tingkat pemahaman Anda secara umum terhadap } \\
\text { mata kuliah yang disajikan secara daring }\end{array}$ & 3,39 & Sedang \\
\hline No & Item Pernyataan & \multirow{2}{*}{ Rata-rata } & \multirow{2}{*}{ Kategori } \\
\hline \multicolumn{2}{|r|}{ B. Aspek Kapabilitas (Kemampuan Dosen) } & & \\
\hline 11. & $\begin{array}{l}\text { Rerata keaktifan dan sikap Anda selama perkuliahan } \\
\text { secara umum baik dan positif }\end{array}$ & 4,15 & Baik \\
\hline \multicolumn{2}{|r|}{ Rata-rata Aspek B } & 4,02 & BAIK \\
\hline \multicolumn{2}{|r|}{ C. Aspek Sarana dan Prasarana } & & \\
\hline 12. & $\begin{array}{l}\text { Materi perkuliahan secara daring telah tersedia } \\
\text { dengan baik }\end{array}$ & 4,05 & Baik \\
\hline 13. & $\begin{array}{l}\text { Saya memiliki perangkat/peralatan pendukung } \\
\text { untuk mengerjakan segala bentuk tugas individu } \\
\text { maupun kelompok sesuai dengan petunjuk yang } \\
\text { diberikan }\end{array}$ & 3,40 & Sedang \\
\hline 14. & $\begin{array}{l}\text { Secara umum, penggunaan aplikasi google classroom } \\
\text { cukup efektif }\end{array}$ & 3,55 & Baik \\
\hline 15. & $\begin{array}{l}\text { Saya tidak memiliki masalah dengan koneksi } \\
\text { internet untuk dapat mengikuti pembelajaran } \\
\text { daring }\end{array}$ & 3,33 & Sedang \\
\hline 16. & $\begin{array}{l}\text { Anda selalu siap mengikuti perkuliahan secara } \\
\text { daring melalui aplikasi google classroom }\end{array}$ & 3,27 & Sedang \\
\hline 17. & $\begin{array}{l}\text { Secara umum, saya puas dengan pembelajaran } \\
\text { daring yang telah dilakukan }\end{array}$ & 3,19 & Sedang \\
\hline \multicolumn{2}{|r|}{ Rata-rata Aspek C } & 3,47 & Sedang \\
\hline & RATA-RATA ASPEK A,B, DAN C & 3,7 & BAIK \\
\hline
\end{tabular}

\section{Persepsi Mahasiswa dalam Proses Belajar Mengajar}

Proses belajar mengajar yang dilaksanakan dalam suatu lembaga pendidikan sangat berperan penting terhadap hasil belajar peserta didik. Setiap proses yang dilakukan memerlukan perencanaan dan persiapan yang matang dan memadai agar diperoleh hasil semaksimal mungkin. Salah satu yang harus dilakukan adalah mempersiapkan bahan atau materi pembelajaran dalam perkuliahan daring, di mana materi tersebut dapat disampaikan dan dipahami oleh mahasiswa dalam kurun waktu tertentu sesuai dengan kontrak perkuliahan/RPS. Berdasarkan hasil kuesioner yang telah dijawab oleh mahasiswa perbankan syari'ah semester II sebagai responden menunjukkan bahwa mahasiswa memiliki persepsi dengan kategori baik terkait proses belajar mengajar dalam perkuliahan secara daring menggunakan aplikasi google classroom. Hal ini dapat dilihat dari kesesuaian jadwal, dan kesesuaian materi dengan kontrak perkuliahan/ RPS, ditemukan bahwa tidak ada kendala yang 
Vol 3 No 2 (2020) 198-209 P-ISSN 2620-295 E-ISSN 2747-0490 DOI: $1047467 /$ elmal.v3i2.569

dialami oleh mahasiswa, bahkan ada kemudahan yang mereka dapatkan dalam mengirimkan tugas/laporan. Bahkan dosen juga dapat langsung memberikan penilaian atas tugas/laporan yang telah dikumpulkan oleh mahasiswa melalui aplikasi google classroom. Namun, terdapat sejumlah mahasiswa sebanyak 39\% $(\mathrm{n}=21)$ yang menyatakan bahwa perkuliahan secara daring tidak memberikan pemahaman yang baik terhadap materi yang diberikan oleh dosen, dikarenakan materi pada mata kuliah matematika ekonomi umumnya membutuhkan penjelasan secara lebih mendalam, detail, dan langsung oleh dosen.

Sedangkan dalam perkuliahan secara daring dengan menggunakan aplikasi google classroom memiliki keterbatasan, terutama dalam hal waktu. Secara khusus, untuk memenuhi kebutuhan dan harapan pembelajar secara daring atau online, desain kurikulum pembelajaran, strategi penyampaian materi yang efektif, penggunaan media teknologi yang berbeda akan memaksimalkan kualitas pembelajaran atau perkuliahan secara daring. Adapun temuan lainnya dalam penelitian ini terdapat suatu faktor penghambat yang sangat mempengaruhi perkuliahan secara daring dengan menggunakan aplikasi google classroom yaitu keterbatasan jaringan internet dan kuota yang dimiliki mahasiswa. Karena pada umumnya tempat tinggal mahasiswa perbankan syari'ah semester II Sekolah Tinggi Agama Islam Jam'iyah Mahmudiyah Tanjung Pura Kabupaten Langkat yang mengikuti perkuliahan secara daring berlokasi di kawasan jaringan internet yang kurang memadai, dan juga dipengaruhi dari jenis kartu atau simcard yang digunakan pada handphone atau android yang digunakan oleh mahasiswa. Bahkan, ada sejumlah mahasiswa sebanyak 20\% ( $\mathrm{n}=13)$ yang memiliki kendala dalam pembelian kuota internet sehingga berakibat pada ketidakhadiran mahasiswa dalam perkuliahan yang dilakukan secara daring. Hal tersebut salah satunya disebabkan oleh keadaan atau faktor ekonomi orang tua.

\section{Persepsi Mahasiswa Terhadap Kapabilitas Dosen}

Kapabilitas seorang dosen dalam melaksanakan perkuliahan secara daring sangat dibutuhkan, agar pelaksanaan pembelajaran yang dilakukan dapat berjalan dengan baik dan mencapai tujuan sesuai dengan yang diharapkan. Kapabilitas merupakan kemampuan aau kecakapan yang dibutuhkan oleh seseorang dalam melakukan sesuatu. Berdasarkan hasil kuesioner, rata-rata kapabilitas dosen termasuk dalam kategori baik. Mahasiswa memberikan persepsi yang positif terhadap kapabilitas dosen dalam perkuliahan secara daring pada mata kuliah matematika ekonomi. Mahasiswa beranggapan dosen telah berusaha semaksimal mungkin mempersiapkan dan menjelaskan materi ajar kepada mahasiswa. Dosen juga berusaha terus merespon pertanyaan yang diajukan oleh mahasiswa selama perkuliahan daring berlangsung, walaupun banyak pertanyaan dan tanggapan yang masuk. Mahasiswa juga menyatakan dosen telah memberikan aturan-aturan atau ketentuan yang berlaku selama perkuliahan daring berlangsung agar pembelajaran berjalan secara terarah dan tercapai tujuan pembelajaran mata kuliah matematika ekonomi. Adapun temuan lainnya dalam penelitian ini yaitu terdapat faktor-faktor 
Vol 3 No 2 (2020) 198-209 P-ISSN 2620-295 E-ISSN 2747-0490 DOI: $1047467 /$ elmal.v3i2.569

pendukung lain seperti pendekatan, interaksi, dan feedback yang secara kontinu diberikan oleh dosen membuat mahasiswa merasakan "kehadiran" dosen pengampu mata kuliah walaupun pembelajaran dilaksanakan secara daring. Sehingga, mahasiswa tetap bisa berpartisipasi secara aktif selama mengikuti perkuliahan daring. Oleh karena itu, Rencana Pembelajaran Semester (RPS) dan Rencana Pembelajaran Harian (RPH) sebaiknya disusun dan dilengkapi sedini mungkin dengan pemilihan strategi maupun metode yang paling efektif, dilengkapi dengan media audio visual sehingga dapat mencapai semua Capaian Pembelajaran Mata Kuliah (CPMK) maupun Sub-CPMK yang telah ditetapkan untuk masing-masing pertemuan. Lebih jauh lagi, dosen dapat merancang pembelajaran berdasarkan metode yang direkomendasikan dalam Permen Ristek Dikti No 44 Tahun 2015, dimana salah satu metode yang paling sesuai untuk perkuliahan daring saat ini adalah Project Based Learning (PBL).

\section{Persepsi Mahasiswa dalam Penggunaan Sarana dan Prasarana}

Sarana dan prasarana merupakan segala sesuatu yang dibutuhkan dan menjadi faktor pendukung atau penunjang atas keberhasilan pembelajaran yang dilakukan. Penggunaan sarana dan prasana masih menjadi sebuah hambatan dan keterbatasan yang dialami oleh sebagian besar mahasiswa dalam melaksanakan pembelajaran secara langsung (tatap muka) maupun secara daring (online). Berdasarkan hasil kuesioner persepsi mahasiswa mengenai aspek penggunaan sarana dan prasarana dalam perkuliahan secara daring termasuk ke dalam kategori sedang. Hal tersebut tampak pada sejumlah mahasiswa yang memiliki persepsi kurang baik (negatif) terhadap penggunaan sarana dan prasarana selama perkuliahan daring berlangsung. Sebanyak 43\% $(n=23)$ responden menyatakan bahwa mereka memiliki permasalahan dengan jaringan atau koneksi internet untuk dapat mengikuti pembelajaran secara daring. Meskipun google classroom sebagai salah satu aplikasi yang umumnya selalu digunakan dalam mendukung perkuliahan mahasiswa secara daring dan tidak membutuhkan kuota yang cukup besar, mahasiswa tetap merasa dan beranggapan bahwa koneksi internetlah penyumbang masalah terbesar terhadap kesuksesan perkuliahan daring yang dilakukan. Kendala lain yang berpengaruh terhadap penggunaan sarana dan prasarana yaitu perangkat belajar yang dimiliki oleh mahasiswa masih belum terpenuhi/memadai, di mana sebagian besar mahasiswa sebesar 91,9\% (n=50) menggunakan handphone android untuk mengikuti perkuliahan daring dan sisanya sebesar 8,1\% (n=4) yang menggunakan perangkat laptop atau personal komputer. Berdasarkan fungsinya, perangkat laptop atau personal komputer lebih baik digunakan dari pada perangkat handphone dalam perkuliahan secara daring, dengan alasan perangkat handphone memiliki lebih banyak keterbatasan untuk mengikuti perkuliahan daring secara maksimal. Secara khusus, jaringan atau koneksi internet merupakan komponen pendukung terselenggaranya perkuliahan secara daring. Ketersediaan internet sangat diperlukan karena karakteristik pembelajaran yang memanfaatkan jaringan internet. Hal ini merupakan tantangan bersama seluruh perguruan tinggi bahkan 


\section{Cl, MITIV Iurnal Kajian Ekonomi \& Bisnis Islam}

Vol 3 No 2 (2020) 198-209 P-ISSN 2620-295 E-ISSN 2747-0490 DOI: $1047467 /$ elmal.v3i2.569

sekolah yang ada di seluruh Indonesia karena kondisi jaringan internet di Ind onesia secara umum masih sangat minim. Kecepatatan akses yang relatif masih lambat tidak hanya dialami di daerah terpencil dan pedesaan, tetapi juga di kota besar.

\section{KESIMPULAN DAN SARAN}

Perkuliahan secara daring pada masa pandemi Covid-19 telah dilaksanakan oleh seluruh Perguruan Tinggi di Indonesia sesuai dengan ketetapan yang telah dikeluarkan oleh pemerintah pada awal tahun 2020. Berdasarkan hal tersebut, berbagai upaya dilakukan untuk melaksanakan perkuliahan secara daring, salah satunya dengan penggunaan aplikasi google classroom pada masa pandemi covid-19. Persepsi positif mahasiswa terkait pelaksanaan perkuliahan secara daring ditemukan dalam dua aspek yaitu aspek proses belajar mengajar dan aspek kapabilitas dosen. Hal ini didukung oleh jadwal perkuliahan yang dilaksanakan secara disiplin dan kemampuan SDM mengelola perkuliahan daring (online), di mana dosen sebagai fasilitator. Sedangkan pada aspek lainnya, yaitu aspek penggunaan sarana dan prasarana, diperoleh persepsi kurang baik (negatif) dengan kendala keterbatasan jaringan internet dan perangkat belajar yang dimiliki oleh mahasiswa dalam mengikuti perkuliahan daring. Berdasarkan temuan dalam penelitian ini, perkuliahan daring dengan menggunakan aplikasi google classroom tetap dilaksanakan hingga akhir semester genap, dan diupayakan dapat berlanjut pada semester selanjutnya dengan menindaklanjuti kendala-kendala yang ada sesuai temuan yang ada dalam penelitian yang telah dilakukan. Harapan lebih lanjut, pelaksanaan perkuliahan secara daring (online) dapat diakses oleh mahasiswa dengan menggunakan aplikasi yang tidak membutuhkan bandwith maupun kuota yang cukup besar.

Namun, dosen dan mahasiswa tetap berkeinginan tinggi agar perkuliahan dapat segera dilaksanakan secara tatap muka agar terjadi pembelajaran yang lebih baik daripada pembelajaran/perkuliahan yang dilaksanakan secara daring. Oleh karena itu, semoga masa pandemi covid-19 ini cepat berlalu, dan hilang dari permukaan bumi ini. Dosen juga memiliki keinginan perkuliahan lebih baik dilaksanakan secara tatap muka agar lebih tercipta pendidikan berkarakter atau berakhlak mulia. Karena, mahasiswa tidak hanya dituntut memiliki ilmu yang tinggi, tetapi juga harus memiliki karakter atau akhlak mulia, yang tentunya dapat diterapkan dalam kehidupan sehari-hari.

\section{DAFTAR PUSTAKA}

Arsyad, Azhar. (2013). Media Peembelajaran. Jakarta: Rajawali Pers.

Asnawi, Noordin. (2018). Pengukuran Usability Aplikasi Google Classroom Sebagai Elearning Menggunakan USE Questionnaire (Studi Kasus: Prodi Sistem Informasi UNIPMA). Research : Journal of Computer, information system, \& technology management, 1 (2), 17-21.

BNBP RI. (2020). Presiden Tetapkan COVID-19 Sebagai Bencana Nasional. 
Vol 3 No 2 (2020) 198-209 P-ISSN 2620-295 E-ISSN 2747-0490 DOI: 1047467/elmal.v3i2.569

Fauziah, Ula Nisa El, dkk. (2019). Penerapan Google Classroom Dalam Pembelajaran Bahasa Inggris Kepada Guru-Guru Bahasa Inggris SMP Di Subang. Abdimas: Jurna Pengabdian Kepada Masyarakat, 2 (20) 183 - 191.

Hapsari, Swita Amallia., Heri Pamungkas. (2019). Pemanfaatan Google Classroom sebagai Media Pembelajaran Online di Universitas Dian Nuswantoro. Wacana: Jurnal Ilmiah Ilmu Komunikasi, 18(2), 225- 233.

Kbbi.kemdikbud.go.id

Kemendikbud. (2020). Surat Edaran Menteri Pendidikan dan Kebudayaan Republik Indonesia Nomor 35952/MPK.A/HK/2020. Mendikbud RI.

Moleong, Lexy J. (2012). Metodologi Penelitian Kualitatif. Bandung : PT Remaja Rosdakarya.

Rozak, A., \& Albantani, A. M. (2018). Desain Perkuliahan Bahasa Arab Melalui Google Classroom. Arabiyat: Jurnal Pendidikan Bahasa Arab Dan Kebahasaaraban, 5(1), 83- 102.

Septantiningtyas, Niken. (2019). Pengembangan Desain Pembelajaran pada Kelas Profesional PGMI Google Classroom. Edudeena, 3 (2), 101-107.

Smaldino, Sharon E., dkk. (2011). Instructional Technology \& Media for Learning: Teknologi Pembelajaran \& Media untuk Belajar. Jakarta: Kencana.

Sugiyono.(2012). Metode Penelitian Pendidikan Pendekatan Kuantitatif, Kualitatif, dan $R \& D$. Bandung: Alfabeta.

Sugiyono. (2014). Memahami Penelitian Kualitatif. Bandung; Alfabeta.

Sujarweni, V. Wiratna. (2014). Metodologi Penelitian. Yogyakarta: Pustakabarupress.

Sukmawati, S., \& Nensia, N. (2019). The Role of Google Classroom in ELT. International Journal for Educational and Vocational Studies, 1 (2), 142-145. https://doi.org/10.29103/ijevs.v1i2.1526 